\title{
Understanding of Identical Politics in the Indonesia Local Election: Critical Analysis of Political Election Context Literature
}

\author{
Sardjana Orba Manullang \\ Universitas Krisnadwipayana, Indonesia \\ Corresponding author email: somanullang@unkris.ac.id
}

\begin{abstract}
This paper aimed to gain an in-depth understanding of the meaning of identity politics in the context of the Indonesian election through critical analysis of the scientific literature of direct elections. We believe it is essential for all citizens to understand identity politics, considering that the success of the regional elections in Indonesia is closely related to the participation of all levels of society, especially intellectuals and policymakers. So for that, the author has collected much literature, and we have studied it carefully to get a deeper understanding. We get to the literature was through an electronic search of the Google Scholar database. Furthermore, our data analysis involves a system of coding, evaluation, and interpretation under the phenomenology approach to obtain valid and reliable answers. After a series of discussion of the results, we can summarize the findings, others Identity politics is a political tool of a group such as ethnicity, ethnicity, culture, religion, or others for specific purposes, for example, as a form of resistance or as a tool to show identity. Themselves a group.

Keywords---identical politics, local election, political election, review literature.
\end{abstract}

\section{Introduction}

The Republic of Indonesia is a country that was born from a kind of resistance to colonialism and European imperialism (Said, 2012; Pennington et al., 2015). The Indonesian people need to be freed from the shackles of foreign imperialism by the Dutch and Japanese. The Javanese people, which constitute the majority of Indonesia, are citizens who comprise several collective-communal standards. It implies a personality between ethnic, racial, and religious encounters and between meetings to unlock the country (Rutten, 2016; van der Muur et al., 2019; Liu \& Lei, 2018). The soul frames a request that is free and liberated from existing everyday life. Freedom from colonialism eventually gave rise to the feelings of individuals who were nationalities, races, and religions within the framework of the archipelago (Erni, 2008; Ediraras et al., 2013). Associations to join then shape the character of the legislative issue as a community steadfastness. The state has agreed to keep the character value starting from the value of solidarity and diversity. It is only a provincial state and nothing more than Indonesia. However, colonialism respects Indonesia, which is an attribute of patriotism itself (Cohen, 2016); (Febrina \& Manullang, 2020); (Sudarso et al., 2020); (Sudarmo et al., 2021).

In the past, the Indonesian state could compete with foreign countries (Aspinall, 2013; Manullang et al., 2020). This choice shows that it cannot compete with other countries because of identity rules. This identity makes the country excited and proud of its people, not a country with its characteristics. The personality state has just been explained in a biased and directional manner in the mind of identity. It cannot be characterized as long as race and religion are still true identities (Masuoka, 2017; Sondel et al., 2018). Patriotism in Indonesia is thought about the people's solidarity in the political sphere and the value of solidarity and national unity. Indonesia must become a composition due to government with personality and fortitude, which is the feeling of a state (Drake, 2019; Gemmill, 1992). Patriotism can be interpreted as a perspective that has been created in the archipelago for a long time. It cannot be denied that Indonesian patriotism was brought to the world as an instrument of development and a problem of legislative personality (Kim \& Schattle, 2012; Hazan, 1996). This is an apparatus associated with expansionism, colonialism, and quality based on a rate "philosophical channel" that ultimately becomes a great nation's quality (Bose, 2017). 
This particular identity is brought into the world from a variety of ways, ranging from likeness, culture, ancestral worship mentality, and similarity in culture, such as parables between religion, class, shame, treatment, such as likeness in personal and historical form (McCrone \& Bechhofer, 2015). The type of identity and patriotism in Indonesia is not the patriotism that exists in western countries. Public personality requires a high level of fortitude in the Indonesian state and should not be trapped in suspicion but in territorial obsession, identity, religion, and associations which are quite troublesome for a single-formed nation (Verheijen \& Darma Putra, 2020). What is happening nowadays routinely only divides the spirit of solidarity and honesty of the Indonesian people. Political identity in Indonesia should not be considered disturbing but also based on a source of values, character, fortitude, and state resilience (Coker, 2019).

According to Alfaqi (2016) efforts to understand Indonesia must be made through the perspective of nationalism, identity politics, and national solidarity. This has become the foundation of the eastern people. So this country must also respect values, be based on character, fortitude, respect land rights, and worship land, with the disposition of respecting land towards land and its relatives. Because that identity has a set of experiences and beliefs, it feels like it has a past and a purpose (Edensor, 2020). The historical background of politics comes from the Greek word Politeia, or polis which means state or city. It is an attitude of fortitude or fellowship, deep average interest, and compassion for a particular encounter as far as steadfastness. In the sense of character, there are two kinds of fortitude: mechanical fortitude and natural fortitude. The three-character developments are intended to form other personalities that can change the construction of society (Georgiadis \& Manning, 2013). The notion of a legislative problem is an interaction that shows a particular character during the time spent forming other meetings or societies.

Identity politics is the political framework that forms the setting for training on target frameworks and carrying out those goals. The identity character may come from the word personality, which implies an alternative nature from the gathering that wins or floods (Straughn \& Feld, 2010). It can also be interpreted as an association of women activists who try to organize the situation of women in the eyes of the public and fight for destructive forms in the general public or fight for the authenticity of character within this framework. It also implies that each individual is united with the individual and that each individual is in an association or clan, and the nature of the association is a tool for shaping personality (Khader, 2012). The term identity politics is a kind of governance problem, a method of showing character and fighting for the authenticity of a state meeting (Moghadam, 2019). Identity politics intends to shape a way of life only as an interaction to develop alternative conferences or gatherings. The word governance is used to describe the political framework and its implementation. The contrast between mechanical fortitude and natural fortitude has the slope of Mount Bromo in East Java. Mechanical fortitude arises from dependence and dependence on others. This value is much more open to mechanical strength in contact than to natural power.

\section{Current Politics and Identical Politics}

The idea of modernizing Islam and identity politics in Indonesia has grown slowly since the beginning of the 20th century (Nurlaelawati, 2010). The way to update Islam through thoughts grew gradually and subsequently influenced the development of the pioneers of Islam. The problem of modernization development in Indonesia was initially a continuation of the "development of sanitation, for example, encouraged by Syekh Muhammad Abduh (1849-1905). The elements of general, liberal, and plural understanding also have essential meanings to emerge. Puppeteers and strict associations in Indonesia as development was change by the Muslim ummah. This is what the current authorities are finally worried about (Fernandes, 2018).

However, there are three internal factors behind political identity. Because behind that, there is a feeling of modernizing the idea of Islam as a spirit of state (Azra, 2019). It is thinking about the requirements for change and renewal and modernization of the framework (the need for reorganization and modernization) of instruction. This is also influenced by the possibility of renewing Islamic circles by Ibn Taimiyyah (d. 1728 H./1328 M.) and other scholars (Hakiki, 2011). The defense of Islam by Harun and Nurcholish is an absolute necessity to understand Islam from top to bottom as a level-headed but strict religion (Madinier, 2015). It must be considered a strict religion with total and broad truth.

Even though Islamic teaching in Indonesia is outdated, as handled by the education system in Islamic boarding schools, Islam does not have an abundance and underdevelopment and inadequate training of Muslims in all parts of life (Hadiz \& Teik, 2011). Then came innovation, namely the progress of the development of the modernization of Islamic ideas. The word innovation means "new" in English. Innovation is a critical term in this investigation that has the significance of alternatives in unexpected ways (Gilsenan, 2013). In Indonesian, innovation is seen as cutting edge time (new age) or standard for a new era (present or present attributes). The word modernization comes from the word modernization (innovation), which was first used by Christians in Quite a while and is described as 
"modernization" in Latin. This is a term used by puritans and pioneers to allude to the Islamic idea of modernization in Indonesia and the West (Mietzner, 2020).

Today's term innovation implies a perspective or strategy or technique for intuition or esp strategy. "innovation" in today's slang (Kamrava, 2011). Because Islam and innovation are traditions that eventually become public contributions. It can also mean "advancing innovation" or "old differences" or a new time (new age) in the present that alludes to the development of modernization of researchers in Indonesia and the impact of these developments. Innovation can be considered a condition and state after tightening (Islam et al., 2017). Today is a development that controls instruction, innovation, and industrialization. Increased innovation can be accepted in terms of a series of experiences and a history of changing events. Innovation is seen as a scientific development seen as an attempt to challenge, in any case (Rosyad, 2019), which will renew strict conventional beliefs and qualities. It can also be seen as inspirational control of education, innovation, and delegate voice-based systems for popular government agencies in Islam (Howell, 2013).

Identity politics is a situation after conservativism or post-rigidity and can even be recognized as an inspiration for citizen privileges and the spread of society (Setiawan et al., 2020). This is not to push some Muslims into a stalemate, and it does not stun some and discover the shocking culture of the Western world. This has also encouraged humanism, scientism, anthropocentrism, and anthropocentrism in the Islamic world (Hidayatulloh, 2012). This is seen as a test for conservative and puritanism thinking about religion and religion. It is also seen as a development that seeks to accommodate customs and beliefs to accommodate belief in adat with new deductions and accommodate old and new reasoning. The pioneering perspective on Islam is a kind of religion, as shown by Ahmed (2013) who described Al-Islam as a biography of Islam. He also explained the development of modernization in Islam as found in historical phases such as advances in science and innovation.

Political identity viewed as postmodernism is a Western influence. It attempts to piece together a current state stands appealing to conservative views as a Western attempt to stop the Ottomans in Turkey nearly ruined. All Islamic characters, personalities, and customs are killed and replaced with pictures, images, and businesses. The West has replaced religion with Western-style schools and headscarves with the use of Western languages. It has returned Arab calls to petition in environmental language and replaced Sharia law with Western-style laws on Islamic marriage (Atmadja, 2010). Islamic modernization has encouraged social disruption in indigenous life and an inability to give the current successful stand to conservative perspectives on religion (Ahmed, 2013).

At a glance, the author observes that Turkey influences the identity politics of the majority in Indonesia; the Islamic world is affected by Islamic change in Egypt (Heryanto, 2015). When this has practically lost its affective on the sacred, his reasoning shows the absence of apparent affection. One of the difficulties for Muslim countries is the ultimate goal of supporting modernization. Efforts are being reacted by Muslim researchers in almost all Muslim countries to promote and dominate the Western training model. The West is logical and realistic. It is even said that social distraction and its seeds. It is argued that social transformation is genuine and that the origins of majority rule have been deduced. West, which is very ethnocentric Islam, is very ethnocentric. On that basis, most Indonesians who are Muslim are trying to reconcile how Islam can still exist through a more identity-based political mouthpiece (Haboddin, 2012). He understands that the way to strengthen identity politics in Indonesia is through politics that are down to earth as most voters.

Longing for Islam as a scientific civilization before the West has also become the background of identity politics. Science is indeed a Western-dominated innovation since the sixteenth century (post-renaissance) in general. The progress of Western modernization consistently, surprising mental and sociological resistance, in the view of Islam Latif (2013). Islamic researchers reacted by showing young students how to run the West. The teaching of pioneering thinking has driven the advancement of the development of innovators in Islam. Investigating innovation in Islam is fundamentalism driven by Islam, as pointed out by Muslim researchers (Pipes, 2017). Muslims need a logical framework that fits their needs, material or deep. The West cannot solve this problem because it contains Western qualities which negate the image of Islam. In contrast to Naquib Alatas, he sees that Muslim researchers are only advancing Western social attributes within the framework of Western information. The tendency of Muslims, especially the masterminds of Islam, is to take steps to make scientific and human progress as limited by the West (Goerzig \& Al-Hashimi, 2014).

Identity politics can be innovation as an engineered development that needs to combat the role of foreign minority domination and hide the flaws of current political work (Aspinall, 2007). It is innovation and typology in Indonesia are among the types of communism today that had their foundation in the development of nineteenthcentury Islamic change in Egypt. It is a response and resistance and a balance to the spread of Western thinking and thinking about majority rule. Muslim reformers founded it in the late nineteenth century. The term innovation is also used to describe (Hilmy, 2013). The development of innovators in Indonesia and post-reform development that can 
also be applied to various countries, such as Pakistan and India. The word innovation has been used to describe other types of innovation since the 1970s. This implies the latest developments trying to replace conventional religious and cultural thinking with 21st-century Islamic thought through identity politics (Hatherell, 2019).

The rationale for identity politics is closely related to the improvement of the role of the majority, which also has implications for improving other perspectives on Islam which is free from the influence of religion, reason, and culture (Mietzner, 2020). These developments are regularly referred to as "Islamic innovation" by his allies as "advanced developments" and "a new type of Islamic communism." It is often seen as a response to innovative Western thinking and other post-progressive Islamic thought strength and power in the Islamic world. That means making Islam more Islamic and making it more delegated to the religion of Islam, compared to the results thereof. It regularly plays the role of Islam as a religion through politics and the state's power (Driessen, 2014).

Since the beginning of the 20th century, Indonesia has developed rapidly with innovation development (Syar'i et al., 2020). The pioneers need to adjust religious reevaluation with the faces of the majority that are pluralistic and open-minded. Most Muslims consider the old artwork cannot demand strict approval based on voting, see Breg Barton, The International Context of the Emergence of Islamic Neo-Modernism in Indonesia. The four minutes that compose each other produce what is now called "social society," defined as "the four portraits of social change" and "the introduction of the foremost society." The phrase "Islamic innovation" signifies the progress of Islamic thought in another structure, a structure that is outside the practice of Islamic fundamentalism (Choueiri, 2010).

Identity politics, in other words, is a type of innovation that depends on the development of innovators of the majority in Indonesia, namely the Muslims (Fauzia et al., 2011). According to him, Islam will be able to move to change if Islam is in the Muslim public political space characterized by identity in the frame of the future of democracy in Indonesia. This is not seen as an inability to maintain the new modernization thinking in Indonesian politics. Moreover, this has led to a lack of creativity and creativity in Islamic thought. Islamic conservatives have proven to be loyal to politics while keeping Indonesia a conservative country. According to Habibi (2017) who analyzes identity politics in Indonesia, he understands that there are three, each of which has its attributes. The Islamic conservation group seeks to change the meaning obtained from the historical background of Islam into today's social history. Many pundits say that reformist Muslim talk is only taking place in the upper working class. The principle of the mission being carried out is trying to liberate Muslims who are poor, reversed (information), and oppressed both actually and ethically (Maarif, 2019). So that is the basis for that they want the Islamic ummah to speak again with Islamic identity utilizing parliament and elections.

Identity politics makes an essential agenda for the Islamic ummah, not a big and heavy agenda as thought by nationalists with activities being a problem of concern and activities reducing the significance of democratic progress in Indonesia (Khamdan \& Wiharyani, 2018). The task of advancing Muslims is on the theme of solid indications from the Koran. Meanwhile, another effort is to invite the Islamic ummah to understand Islam by revealing central information (sharpness) about the original Islam (sane Islam). The key offered focuses on individual Islam, and the individual world, individual religions (Rozikan \& Fitriana, 2017).

The significance of Islam hinges on its slogans, for example, "Emancipatory" and "Revelations in the Koran." The key to that idea is to choose to understand Islam as a whole and have a rational belief in the emotional value of being represented wisely. Innovators who disagree with identity politics are individuals or figures who can overcome typologies of thought (Nur \& Makmur, 2020). According to the author, they are not indigenist; they are a group of scholars who believe in Islam as a collective solution. The neo-pioneers can be characterized as innovation. Innovation can be used to offer personality to the trends of Islamic ideas that have emerged during the last few years. Identity politics innovators were not very well known during the New Order era about thinking (none of them were well known), which implies nothing unique compared to the Islamic figures currently being considered. The three typologies of Indonesian Islamic innovation above are everyday Islam, civilizational Islam, and authoritative Islam (Rouf, 2016; Suhardi et al., 2020; Aslan, 2018; Aslan et al., 2020; Aslan \& Hifza, 2019). The core of every thought is about the development of objective innovation in Islam and the progress of Islam, especially on the issue of secularization in Islam, especially in the modernization of Islamic civilization. This is why identity politics is needed to represent the Islamic ummah as most of the Indonesian nation. For this reason, Nasrudin (2018) views that identity politics as a political representation of the Islamic ummah in Indonesia, and this is very natural wherever people need a spirit of togetherness in the state container. So naturally, it should not be seen as wrong, let alone a threat to democracy. 


\section{Method}

We understand what and how politics are identical in the electoral system in Indonesia is very important and exciting to study recently. So that we can easily find the answer to the study problem, the study design choice is very suitable, namely reviewing literature discussing issues of democracy and identity politics in Indonesia. For that, we compiled literature via an electronic search on Google scholar. When we carried out this study, Indonesia, like other countries, was currently in the pandemic response period. So studies that rely on secondary data are very relevant. After collecting the data, we will examine it involving the coding system, evaluation, interpretation, depth, and drawing conclusions that will become valid and reliable data findings. To make it easier to report the results, we selected the descriptive method under a qualitative study. We followed the study guide Elo et al. (2014) in their study of the qualitative content analysis method by focusing on the validity and trustworthiness of the findings.

\section{Result and Discussion}

In this section, we will present the results of the review of this study which originated from the findings of experts on identity politics in the regional head elections and the choice of legislators in Indonesia. The first finding is from Harjanto (2011) about domestic politics and institutional politics of political parties in Indonesia. The task of ideological groups during the time spent choosing authority and filling public office is essential. However, due to weak systematization and collection, there is a tendency to fortify legislative issues of family relations. Candidates from value groups and quality of officeholders and administrative boundaries are problematic. This pattern seems indistinguishable from the decline in party systematization and the logic of governance with prevailing majority rules.

Since the Pilkada Law was passed, identity politics in Indonesia has become increasingly visible. For example, Nasrudin (2018) proves how the personality of legislative issues and political portrayals has been since the case was concentrated in the 2018-2022 DKI Regional Election). The measure of majority rule in Indonesia cannot be distinguished from the direction of the problem and the description of the personality of the government. Exploration is centered on researching the second round of DKI regional decisions in the 2018-2022 period. The results of the study show that governmental problems affect the size of the majority rule.

Likewise, Suharyanto (2014) examined how the political support of Chinese community groups in regional head decisions. This investigation plans to understand how the political participation of the Chinese people in Indonesia and what Chinese groups should see in the Binjai city elections round in 2010. The method of study is through periodic testing of $10 \%$ of the population. The various information procedures used are perception, survey, and meeting. The information obtained in the investigation is checked using a clear screening strategy, then described using an iteration table. In light of the perceptual examination, surveys and meetings then become a discussion about exploration results.

Furthermore, Lestari (2019) show how the 2017 Jakarta elections with the dynamics of identity politics in Indonesia. This paper hopes to get answers related to the 2017 DKI Jakarta local political decisions through elements of political character in Indonesia. The consequences of this investigation can contribute to existing partners to prevent the widespread nature of legislative issues of a character in Indonesia. This study uses a subjective methodology that is a logical exploration that emphasizes the importance of associating human behavior in certain circumstances.

The following review is Fautanu et al. (2020) who managed to understand the political character of the 2017 DKI Jakarta regional elections from the perspective of Nurcholish Madjid's political thought. The rise of examples of firm disrespect and the increase of 212 silent activities is an aid for Muslims to pick up pioneers who are of the same faith. The purpose of centralization and examination in this article is to see Nurcholish Madjid's political considerations in the rise of legislative personality problems in the 2017 DKI Regional Election. They are characterized as activeness in fighting for achievement, moving Muslim groups as a personality problem in the legislature.

The purpose of identity politics, among others, was found in the study of Hemay \& Munandar (2016) where they succeeded in understanding how identity politics and the image of a candidate for governor on voter behavior. The behavior of Bengkulu-political citizens in 2015 was heavily influenced by the possible personality and appearance of the deputy leader. The clan or national character factors, along with the descriptions of the characters, can make a solid contribution to shaping voter behavior in the Bengkulu 2015 local election.

Recently the emergence of the phenomenon of identity politics is not unreasonable. According to Sari (2016) this is where he said that the revival of Islamic identity politics was in the arena for the election for the governor of 
Jakarta. This paper discusses the restoration of the problem of government with an Islamic personality in the political decisions of the governor of Jakarta. He argued that the legislative issue of character, nationality, and religion was deliberately built by the political elite to seize power. The exploration used is phenomenology using a subjective methodology. The results show that Islam is reviving for a variety of reasons. The problem of personality governance occurs through efforts to build self-portraits and mental nurture with self-confidence as Muslims who are ashamed of the goals required by individual Muslims. Choose people who share the same beliefs and religions.

According to Saputra (2017) identity politics is part of an effort to strengthen the existence of the majority of Muslims in Indonesia. Identity politics and issues of religious harmony in Manokwari. This exploration seeks to reveal the history and foundations, progress, and impacts of the character problems of government in Manokwari City. The aim is to follow the basis and influence of government issues with a personality on the climate of interreligious relations. Discovery shows that personality. The development of legislative problems in Manokwari began to emerge a few moments later. The destruction of the New Order. The product must be organized into guidelines, but guidance inward may destroy lives and the agreement between tight networks.

Furthermore, Rantung (2018) also examines identity politics among the Islamic ummah; he also examines political theology for the justice of the church's theological responses in the midst of strengthening identity politics. About new circumstances, the congregation is available and struggling with its difficulties. The community is enhancing the character of the government that emerged after the New Order. The congregation responded to legislative character with a political philosophy designed towards social justice for harmony and success. They are fighting for the privilege of the helpless, the poor, the persecuted and bringing justice and victory as the goal of the good news of Jesus Christ in bringing social justice and bringing harmony to all individuals. This research is a political philosophy for social justice with the ultimate goal of social justice. The various information strategies used are subjectively expressive. The examination model used is subjective, given the side effects of concentrated writing from multiple sources.

The findings of Kurniawan (2017) examine elements of Indonesian architecture and post-reform representations of 'political character.' The strengthening of the legislative character in Indonesia after the changes gave birth to new building structures scattered in various regions in Indonesia. Social personality identified with character has become part of the legislature's identity, which according to some political eyewitnesses, it is asserted that the elites and rulers use it for the benefit of issues of forced governance.

\section{Discussion}

This section will discuss the results of our study, which aims to understand how identity politics is in the electoral arena and natural choice in Indonesia. So for the first time, we confirm that based on the exposure in the results section, it has indicated that we have achieved the objectives of this study. Apart from various reasons, identity politics have appeared since several regional elections in Indonesia, especially in big cities such as DKI Jakarta and some other towns and districts. We see that these identity politics emerges as part of the political dynamics itself, which continues by certain groups who want to rise with a conservative and collective spirit. Our findings are also very in line with our expectations, where we want to understand the motives and causes of the identity politics phenomenon that emerged along with the passing of the regional election constitution in this country.

When actualized by the current political conditions in Indonesia, this very political origin appears, with the reason for regional election regulations since Indonesia entered the reform era where election regulations have increasingly opened up public spaces. This never happened during the general elections during the New Order era with a more authoritarian regime where the civilian role was absent for politics, such as the identity of specific religions. This is following Noor (2016), where he understands pragmatic political behavior in contemporary political life by reducing the role of political ideology in the reform era. Another study, for example, Hambali (2014) through his research on the theme of post-reform post-conflict local elections in Indonesia, which is increasingly democratic and following the demands of the reform era.

As for our unexpected findings, we briefly describe that experts in the country wrote most of the data we studied. We should have had to discuss the findings of foreign researchers because we believe that the results by foreign observers may be more comprehensive and accurate. This was the case when our search by electric means mostly turned up the findings of national publications. However, this is not too worrying, and we believe these findings cover the problems we address. Their results may not be what the department coveted, but they fit perfectly with what everyone considers the phenomenon of identity politics to occur, and they are highly relevant for publication. 


\section{Conclusions}

This section concludes that this study aims to understand how identity politics in Indonesia's regional elections had achieved our goal where identity politics occurred when Indonesia entered the reform era. Identity politics is natural in line with the political dynamics of a nation. Even though some parties have commented on this kind of political trend, it is not like their concern. Finally, we hope that this finding will add to a new understanding of the world of politics in the era of autonomy and land reform, which is getting better the quality of democracy every day.

\section{Acknowledgments}

Without the support of colleagues and supervisors from the university and funding support from the Ministry of Research and Technology, our paper would be meaningless. So on that basis, we are very grateful for all the support above, from the beginning to the time of writing the report and with all the input and feedback we once again arrange thousands of thanks for our paper with the topic "Understanding of Identical Politics in the Indonesia Local Election:

Critical Analysis of Political Election Context Literature "has been completed according to plan.

\section{References}

Ahmed, A. S. (2013). Islam under siege: Living dangerously in a post-honor world. John Wiley \& Sons.

Alfaqi, M. Z. (2016). Memahami Indonesia melalui prespektif nasionalisme, politik identitas, serta solidaritas. Jurnal Ilmiah Pendidikan Pancasila Dan Kewarganegaraan, 28(2).

Aslan. (2018). Dinamika Pendidikan Islam di Zaman Penjajahan Belanda. Syamil: Jurnal Pendidikan Agama Islam (Journal of Islamic Education), 6(1), 39-50. https://doi.org/10.21093/sy.v6i1.1024

Aslan \& Hifza. (2019). Kurikulum Pendidikan Masa Penjajahan Jepang Di Sambas. Edukasia Islamika, 4(2), 171188. https://doi.org/10.28918/jei.v4i2.2295

Aslan, Hifza, \& Suhardi, M. (2020). Dinamika pendidikan islam di thailand pada abad 19-20. Nazhruna: Jurnal Pendidikan Islam, 3(1), 38-54. https://doi.org/10.31538/nzh.v3i1.476

Aspinall, E. (2007). From Islamism to Nationalism in Aceh, Indonesia. Nations and Nationalism, 13(2), 245-263.

Aspinall, E. (2013). A nation in fragments: Patronage and neoliberalism in contemporary Indonesia. Critical Asian Studies, 45(1), 27-54.

Atmadja, N. B. (2010). Ajeg Bali; Gerakan, Identitas Kultural, dan Globalisasi: Gerakan, Identitas Kultural, dan Modernisasi. LKIS Pelangi Aksara.

Azra, A. (2019). Pendidikan Islam: Tradisi dan Modernisasi di Tengah Tantangan Milenium III. Prenada Media.

Bose, A. (2017). Frantz Fanon and the Politics of Solidarity: On the Practice of Third World Intercontinentalism [PhD Thesis]. UCLA.

Choueiri, Y. M. (2010). Islamic Fundamentalism 3rd Edition: The Story of Islamist Movements. A\&C Black.

Cohen, M. I. (2016). Inventing the performing arts: Modernity and tradition in colonial Indonesia. University of Hawaii Press.

Coker, C. (2019). The rise of the civilizational state. John Wiley \& Sons.

Drake, C. (2019). National integration in Indonesia: Patterns and policies. University of Hawaii Press.

Driessen, M. D. (2014). Religion and democratization: Framing religious and political identities in Muslim and Catholic societies. Oxford University Press.

Edensor, T. (2020). National identity, popular culture and everyday life. Routledge.

Elo, S., Kääriäinen, M., Kanste, O., Pölkki, T., Utriainen, K., \& Kyngäs, H. (2014). Qualitative content analysis: A focus on trustworthiness. SAGE Open, 4(1), 2158244014522633.

Erni, C. (2008). The concept of indigenous peoples in Asia: A resource book. IWGIA.

Ediraras, D. T., Rahayu, D. A., Natalina, A., \& Widya, W. (2013). Political marketing strategy of Jakarta Governor Election in the 2012s. Procedia-Social and Behavioral Sciences, 81, 584-588. https://doi.org/10.1016/j.sbspro.2013.06.480

Fautanu, I., Buhori, M., \& Gunawan, H. (2020). Politik Identitas dalam Pilkada DKI Jakarta Tahun 2017: Perspektif Pemikiran Politik Nurcholish Madjid. Politicon: Jurnal Ilmu Politik, 2(2), 87-112.

Fauzia, A., Prihatna, A. A., Abubakar, I., al-Makssary, R., Pranawati, R., Aziz, S. A., Hidayati, S., \& Kamil, S. (2011). Islam di ruang publik: Politik identitas dan masa depan demokrasi di Indonesia. Center for the Study of Religion and Culture (CSRC).

Febrina, M. Y., \& Manullang, S. O. (2020). Trade Secret Protection as Part of Intellectual Property System: A Comparative Study of Indonesian and United States of America Trade Secret Law. Jurnal Mahkamah: Kajian Ilmu Hukum Dan Hukum Islam, 5(2), 193-212. 
Fernandes, A. (2018). Politik Identitas dalam Pemilu 2019: Proyeksi dan Efektivitas. Centre for Strategic and International Studies.

Georgiadis, A., \& Manning, A. (2013). One nation under a groove? Understanding national identity. Journal of Economic Behavior \& Organization, 93, 166-185.

Gilsenan, M. (2013). Recognizing Islam (RLE Politics of Islam): An Anthropologist's Introduction. Routledge.

Gemmill, G. (1992). Political risk and market efficiency: tests based in British stock and options markets in the 1987 election. Journal of Banking \& Finance, 16(1), 211-231. https://doi.org/10.1016/0378-4266(92)90086-F

Goerzig, C., \& Al-Hashimi, K. (2014). Radicalization in Western Europe: Integration, Public Discourse and loss of identity among Muslim communities. Routledge.

Habibi, M. (2017). Analisis politik identitas di Indonesia.

Haboddin, M. (2012). Menguatnya politik identitas di ranah lokal. Jurnal Studi Pemerintahan, 3(1).

Hadiz, V. R., \& Teik, K. B. (2011). Approaching Islam and politics from political economy: A comparative study of Indonesia and Malaysia. The Pacific Review, 24(4), 463-485.

Hakiki, K. M. (2011). Politik Identitas Agama Lokal (Studi Kasus Aliran Kebatinan). Analisis: Jurnal Studi Keislaman, 11(1), 159-174.

Hazan, R. Y. (1996). Presidential parliamentarism: Direct popular election of the Prime Minister, Israel's new electoral and political system. Electoral Studies, 15(1), 21-37. https://doi.org/10.1016/0261-3794(94)00003-4

Hambali, M. A. (2014). Pemilukada Pasca Reformasi di Indonesia. Rechtstaat, 8(1).

Harjanto, N. (2011). Politik Kekerabatan dan Institusionalisasi Partai Politik di Indonesia. Analisis CSIS, 4O(2), 138159.

Hatherell, M. (2019). Political representation in Indonesia: The emergence of the innovative technocrats. Routledge.

Hemay, I., \& Munandar, A. (2016). Politik Identitas dan Pencitraan Kandidat Gubernur terhadap Perilaku Pemilih. POLITIK, 12(1), 1737.

Heryanto, A. (2015). Identitas dan kenikmatan. Kepustakaan Populer Gramedia.

Hidayatulloh, Z. (2012). Islam dan Humanisme menurut Seyyed Hossein Nasr [PhD Thesis]. Pascasarjana UIN Sumatera Utara.

Hilmy, M. (2013). The Politics of Retaliation: The Backlash of Radical Islamists to the Deradicalization Project in Indonesia. Al-Jami'ah: Journal of Islamic Studies, 51(1), 129-158.

Howell, J. D. (2013). 'Calling'and 'Training': Role Innovation and Religious De-differentiation in Commercialised Indonesian Islam. Journal of Contemporary Religion, 28(3), 401-419.

Islam, M. A., Agarwal, N. K., \& Ikeda, M. (2017). Effect of knowledge management on service innovation in academic libraries. IFLA Journal, 43(3), 266-281.

Kamrava, M. (2011). Innovation in Islam: Traditions and contributions. Univ of California Press.

Khader, F. R. (2012). The Malaysian experience in developing national identity, multicultural tolerance and understanding through teaching curricula: Lessons learned and possible applications in the Jordanian context. International Journal of Humanities and Social Science, 2(1), 270-288.

Khamdan, M., \& Wiharyani, W. (2018). Mobilisasi Politik Identitas dan Kontestasi Gerakan Fundamentalisme. AlTahrir: Jurnal Pemikiran Islam, 18(1), 193-218.

Kim, S., \& Schattle, H. (2012). Solidarity as a unifying idea in building an East Asian community: Toward an ethos of collective responsibility. The Pacific Review, 25(4), 473-494.

Kurniawan, K. R. (2017). Dinamika Arsitektur Indonesia dan Representasi 'Politik Identitas' Pasca Reformasi. NALARs Jurnal Arsitektur, 17(1), 65-78.

Latif, Y. (2013). Genealogi Intelegensia: Pengetahuan \& Kekuasaan Inteligensia Muslim Indonesia Abad XX. Kencana.

Liu, D., \& Lei, L. (2018). The appeal to political sentiment: An analysis of Donald Trump's and Hillary Clinton's speech themes and discourse strategies in the 2016 US presidential election. Discourse, Context \& Media, 25, 143-152. https://doi.org/10.1016/j.dcm.2018.05.001

Lestari, D. (2019). Pilkada DKI Jakarta 2017: Dinamika Politik Identitas di Indonesia. JUPE: Jurnal Pendidikan Mandala, 4(4), 12-16.

Maarif, A. S. (2019). Membumikan Islam. IRCiSoD.

Madinier, R. (2015). Islam and politics in Indonesia: The Masyumi party between democracy and integralism. NUS Press.

Manullang, S. O., Chauhan, R., \& Suthar, B. (2020). A Legal and Economic Study of Selected Private Sector Bank: Performance Evaluation Pre and Post-merger. Organization, 7(11).

Masuoka, N. (2017). Multiracial identity and racial politics in the United States. Oxford University Press. 
McCrone, D., \& Bechhofer, F. (2015). Understanding national identity. Cambridge University Press.

Mietzner, M. (2020). Authoritarian innovations in Indonesia: Electoral narrowing, identity politics and executive illiberalism. Democratization, 27(6), 1021-1036.

Moghadam, V. M. (2019). Identity politics and women: Cultural reassertions and feminisms in international perspective. Routledge.

Nasrudin, J. (2018). Politik identitas dan representasi politik (Studi kasus pada Pilkada DKI periode 2018-2022). Hanifiya: Jurnal Studi Agama-Agama, 1(1), 34-47.

Noor, F. (2016). Perilaku politik pragmatis dalam Kehidupan politik Kontemporer: Kajian atas menyurutnya peran ideologi politik di Era reformasi. Masyarakat Indonesia, 40(1), 57-74.

Nur, A., \& Makmur, Z. (2020). Implementasi Gagasan Keindonesiaan Himpunan Mahasiswa Islam; Mewujudkan Konsep Masyarakat Madani Indonesian Discourse Implementation of Islamic Student Association; Realizing Civil Society Concept. Jurnal Khitah, l(1).

Nurlaelawati, E. (2010). Modernization, tradition and identity: The Kompilasi Hukum Islam and legal practice in the Indonesian religious courts (Vol. 4). Amsterdam University Press.

Pennington, N., Winfrey, K. L., Warner, B. R., \& Kearney, M. W. (2015). Liking Obama and Romney (on Facebook): An experimental evaluation of political engagement and efficacy during the 2012 general election. Computers in Human Behavior, 44, 279-283. https://doi.org/10.1016/j.chb.2014.11.032

Pipes, D. (2017). In the path of God: Islam and political power. Routledge.

Rantung, D. A. (2018). Teologi politik untuk keadilan Respons Teologis Gereja di Tengah Menguatnya Politik Identitas. Voice of Wesly, 2.

Rosyad, A. M. (2019). The urgency of learning innovation on islamic religious study (urgensi inovasi pembelajaran dalam pendidikan agama islam): Learning Innovation, Islamic Religious Study, Learning Method. Al-Afkar, Journal for Islamic Studies, 2(1, January), 64-86.

Rouf, M. (2016). Memahami Tipologi Pesantren dan Madrasah sebagai Lembaga Pendidikan Islam Indonesia. TADARUS, 5(1), 68-92.

Rozikan, M., \& Fitriana, S. (2017). Penguatan konseling Islami melalui perjalanan tasawuf dalam meraih kebahagiaan individu. Konseling Religi: Jurnal Bimbingan Konseling Islam, 8(1).

Rutten, R. (2016). Indigenous people and contested access to land in the Philippines and Indonesia. Kasarinlan: Philippine Journal of Third World Studies, 30(2, 1), 1-30.

Said, E. W. (2012). Culture and imperialism. Vintage.

Saputra, A. (2017). Menguatnya Politik Identitas dan Problem Kerukunan Beragama di Manokwari. Mimikri, 3(1), $15-27$.

Sari, E. (2016). Kebangkitan Politik Identitas Islam Pada Arena Pemilihan Gubernur Jakarta. KRITIS: Jurnal Ilmu Sosial Dan Ilmu Politik Universitas Hasanuddin, 145-156.

Setiawan, M. C. A., Ginting, G. K. N., \& Ilmar, A. (2020). The Relationship Between Identity Politics and Trade Protectionism Under Donald Trump's Administration. Journal of Political Issues, 2(1), 58-68.

Straughn, J. B., \& Feld, S. L. (2010). America as a "Christian nation"? Understanding religious boundaries of national identity in the United States. Sociology of Religion, 71(3), 280-306.

SUDARMO, Nugraha, M. S., MARDHIAH, R. I.liow, F. E., \& ASLAN. (2021). The Identification of Online Strategy Learning Results While Students Learn from Home During the Disruption of the COVID-19 Pandemic in Indonesia. Journal of Contemporary Issues in Business and Government, 27(2), 1950-1956. https://doi.org/10.47750/cibg.2021.27.02.205

Sudarso, A., Purba, B., Ardiana, D. P. Y., Manullang, S. O., Karim, A., Purba, P. B., Muliana, M., Siagian, V., Siregar, M. N. H., \& Jamaludin, J. (2020). Konsep E-Bisnis. Yayasan Kita Menulis.

Sondel, B., Baggett, H. C., \& Dunn, A. H. (2018). "For millions of people, this is real trauma": A pedagogy of political trauma in the wake of the 2016 US Presidential election. Teaching and Teacher Education, 70, 175-185. https://doi.org/10.1016/j.tate.2017.11.017

Suhardi, M., Mulyono, S., Syakhrani, H., Aslan, A., \& Putra, P. (2020). Perubahan kurikulum lembaga pendidikan Islam di Sambas pada masa Kesultanan Sambas. Ta'dibuna: Jurnal Pendidikan Islam, 9(1).

Suharyanto, A. (2014). Partisipasi politik masyarakat Tionghoa dalam pemilihan kepala daerah. JPPUMA: Jurnal Ilmu Pemerintahan Dan Sosial Politik UMA (Journal of Governance and Political Social UMA), 2(2), 151-160.

Syar'i, A., Hamdanah, H., \& Akrim, A. (2020). The Development of Madrasa Education in Indonesia. Revista Argentina de Clínica Psicológica, 29(4), 513-523.

van der Muur, W., Vel, J., Fisher, M. R., \& Robinson, K. (2019). Changing indigeneity politics in Indonesia: From revival to projects. Taylor \& Francis. 
Verheijen, B., \& Darma Putra, I. N. (2020). Balinese cultural identity and global tourism: The Garuda Wisnu Kencana Cultural Park. Asian Ethnicity, 21(3), 425-442. 